\title{
Post-operative analgesic technique in laparoscopic cholecystectomy: Comparison of local instillation with bupivacaine vs intravenous butorphanol vs intercostal nerve block with bupivacaine
}

\author{
*Rajesh Angral, Dr Seema Lachala², Dr Satyedev Gupta ${ }^{3}$ \\ Registrar $^{1}$, Postgraduate ${ }^{2}$, Professor and Head Anaesthesia ${ }^{3}$, Department of Anaesthesiology and \\ Intensive Care, Govt. Medical College, Jammu ( $\&$ \&), India.
}

*Corresponding author: angralr@yahoo.com

\begin{abstract}
Background
Present study was undertaken to evaluate an optimal analgesic technique which is safe, effective, feasible and devoid of side effects and complication for post-operative analgesia in patients undergoing laparoscopic cholecystectomy. The techniques under study were parenteral opioids or local intraperitoneal instillation and port-site infiltration with bupivacaine hydrochloride (HCL) or intercostal nerve block with bupivacaine $\mathrm{HCl}$.
\end{abstract}

\begin{abstract}
Materials and methods
The study was a prospective, double blind, randomized controlled trial. 100 American Society of Anaesthesiologists (ASA) grade I and II patients of either sex between the age group 20-60yrs undergoing laparoscopic cholecystectomy under general anaesthesia (GA) were randomly allocated into IV groups of 25each.Group I (IP) received intraperitoneal instillation with $15 \mathrm{ml}$ of $0.375 \%$ bupivacaine and port site infiltration with $10 \mathrm{ml}$ of $0.25 \%$ bupivacaine, group II (ICNB) received bilateral intercostal nerve block with $0.25 \%$ bupivacaine (posterior approach, $\mathrm{T}_{5}-\mathrm{T}_{11}$ ), group III (iv BUT) received intravenous butorphanol $20 \mu \mathrm{g} \mathrm{kg}^{-1}$ and group IV (CONT) received analgesia with injection diclofenac sodium $75 \mathrm{mg}$ intramuscular when Visual Analogue Scale (VAS) was $\geq 6$ at the end of surgery. Post operatively pain using visual analogue scale (VAS), shoulder pain, duration of analgesia, haemodynamic variables, sedation score, rescue analgesic and side effects were observed for 24 hours and analysed statistically.

\section{Results}

We found that intercostal nerve block produced effective analgesia of longer duration $(9.48 \pm 4.44 \mathrm{hrs})$ with almost negligible side effects, whereas i.v. butorphanol produced excellent analgesia but of shorter duration $(5.04 \pm 1.73 \mathrm{hrs})$, with slightly more incidence of nausea and vomiting. Intraperitoneal instillation and port site infiltration with bupivacaine provided comparable analgesia $(6.54 \pm 4.63 \mathrm{hrs})$ with no major side effects.
\end{abstract}

\section{Conclusion}

Intercostal nerve block is a safe and effective analgesia technique of longer duration with almost negligible side effects.

Keywords: laparoscopic cholecystectomy, bupivacaine, butorphanol, pain

\section{Introduction}

Pain is "an unpleasant sensory and emotional experience associated with actual or potential tissue damage ${ }^{1}$.

The introduction of laparoscopic cholecystectomy by Mouret in 1987, Dubois in 1988 and McKernan / Saye in the same year has opened up a new dimension in minimally invasive surgery. A number of reports have highlighted its advantages of reduced post operative pain, reduced hospital stay, decreased morbidity, earlier return to work and cost effectiveness as compared to conventional cholecystectomy ${ }^{2}$. Interestingly, the type of pain after laparoscopy differs considerably from that seen after laparotomy. Laparotomy results mainly in parietal pain(abdominal wall), whereas patients complain more of visceral pain after laparoscopy ${ }^{3}$. Finally, shoulder pain secondary to diaphragmatic irritation as a result of $\mathrm{CO}_{2}$ pneumoperitoneum is a frequent postoperative observation after laparoscopy ${ }^{4}$. 
Inadequately treated pain may lead to splinting, loss of sighing and decrease of vital capacity and these may contribute to post-operative pulmonary morbidity ${ }^{5}$.Although thought to result in less post-operative pain, recent studies have shown that patients may experience considerable pain after laparoscopic cholecystectomy. Being a relatively new procedure, there is no general agreement on effective post-operative pain control $^{6}$.

We performed this study to compare and evaluate the duration and quality of three postoperative analgesic techniques in laparoscopic cholecystectomy: intraperitoneal (IP) instillation and port site infiltration with bupivacaine, intercostal nerve block with bupivacaine (ICNB) ( $\mathrm{T}_{5}-\mathrm{T}_{11}$ )and i.v. butorphanol(iv BUT).

\section{Patients and Methods}

After hospital ethics committee approval and informed written consent from patients a total of 100 ASA Grade I and II patients of either sex between the age group 20-60 years undergoing laparoscopic cholecystectomy under GA were randomly allocated into four groups of 25 patients each. Patients with bleeding disorders, systemic diseases, acute cholecystitis, hypersensitivity to local anaesthetics (LA), opioids and non-steroidal anti-inflammatory drugs, mental disorder and patients converted to conventional cholecystectomy by surgeons due to any reason were not included in the study.

Patients were prepared by overnight fasting and premedicated with alprazolam $0.25 \mathrm{mg}$ per oral on previous night. On the morning of surgery they were premedicated with alprazolam 0.25 $\mathrm{mg}$ per oral, glycopyrrolate $0.2 \mathrm{mg}$ and diclofenac sodium $75 \mathrm{mg}$ i.m. 45 minutes before surgery.

In the operation theatre, i.v line was established; patient was catheterised and connected to monitors to measure: Pulse Rate (PR), Systolic Blood Pressure (SBP), Diastolic Blood Pressure (DBP), Mean Blood Pressure (MBP), Oxygen Saturation $\left(\mathrm{SpO}_{2}\right)$, and ECG. Patients were given i.v. granisetron $2 \mathrm{mgas}$ an antiemetic.

Induction was carried with $2 \mathrm{mg} / \mathrm{kg}$ propofol and endotracheal intubation was facilitated using vecuronium bromide $0.1 \mathrm{mg} / \mathrm{kg}$ body weight. Anaesthesia was maintained using $\mathrm{N}_{2} \mathrm{O}$ in $\mathrm{O}_{2}(66 \%$ : $33 \%)$ along with isoflurane $0.5 \%$ and incremental doses of vecuronium bromide as and when required. A nasogastric tube was introduced and the laparoscopic procedure was undertaken in a standard fashion. Intraabdominal pressure was maintained between $10-12 \mathrm{mmHg}$.

The residual muscle relaxation was reversed at the end of surgery with neostigmine $0.05 \mathrm{mg} / \mathrm{kg}$ and glycopyrrolate $0.01 \mathrm{mg} / \mathrm{kg}$ body weight. The nasogastric tube was removed after recovery from anaesthesia.

At the end of laparoscopic cholecystectomy patients were randomly allocated to 4 groups.

Group I (IP): Received local intraperitoneal instillation with $15 \mathrm{ml}$ of $0.375 \%$ bupivacaine and port site infiltration with $10 \mathrm{ml}$ of $0.25 \%$ bupivacaine.

Group II (ICNB): Received bilateral intercostal nerve block with $0.25 \%$ bupivacaine, $2.5 \mathrm{ml}$ for each segment $\left(\mathrm{T}_{5}-\mathrm{T}_{11}\right)$ using posterior approach.

Group III(iv BUT):Received intravenous butorphanol $20 \mu \mathrm{g} / \mathrm{kg}$.

Group IV(CONT): $\quad$ Received analgesia as and when needed depending on VAS.

Parameters monitored

Post-operative pain was assessed using VAS: consisting of $10 \mathrm{~cm}$ scale from 0 (no pain) to 10 (worst imaginable pain). Shoulder pain: recorded on a 5 point scale.

1-No pain

2-Discomfort in shoulder but no pain

3-Light pain (no analgesia required)

4-Moderate pain (analgesia required)

5-Severe pain (analgesia and sedation required)

Rescue analgesic was diclofenac sodium $75 \mathrm{mg}$ i.m. when $\mathrm{VAS} \geq 6$. The degree of sedation was assessed by using Ramsay sedation scale. Haemodynamic variables and side effects of drugs were also observed. All the above parameters were assessed at $0,1,2,4,8,12$ and $24 \mathrm{hrs}$.

A sample size of approximately 22 per group was needed to demonstrate a difference of $25 \%$ in VAS considering an $\alpha$ of $95 \%$ (.05) and power of the study as $80 \%$. Data was analyzed 
statistically using ANOVA, t-test, Borferronis ttest. $\mathrm{P}$ valve $<0.05$ was taken as significant.

\section{Results}

Mean post-operative (Ramsay) sedation score at $0,1,2,4,8,12,16$ and 24hrs in group I(IP), group II(ICNB), group III(iv BUT) and group $\mathrm{IV}(\mathrm{CONT})$ is 2 , which is comparable in all the four groups and statistically insignificant ( $p$ value $>0.05$ ).

Table 1: Demographic variables of patients

\begin{tabular}{|l|l|l|l|l|l|}
\hline & I(IP) & II(ICNB) & $\begin{array}{l}\text { III(iv } \\
\text { BUT) }\end{array}$ & IV(CONT) & P value \\
\hline Age(yrs) & 35.08 & $36.72 \pm$ & $37.64 \pm$ & $32.96 \pm$ & N.S. \\
Mean \pm & \pm 8.26 & 9.85 & 7.39 & 9.63 & \\
S.D & & & & & \\
Weight & $61.36 \pm$ & $63.36 \pm$ & $64.52 \pm$ & 61.28 & N.S \\
$\begin{array}{l}\text { (Kgs.) } \\
\text { Mean } \pm\end{array}$ & 5.70 & 5.73 & 6.31 & \pm 6.50 & \\
S.D & & & & & \\
Sex(M:F) & $4: 21$ & $6: 19$ & $5: 20$ & $7: 18$ & N.S. \\
\hline
\end{tabular}

All the four groups were comparable in age, weight and sex distribution ( $p>0.05)$.

Table 2: Mean post-operative VAS at different time intervals

\begin{tabular}{|c|c|c|c|c|c|}
\hline Hours & $\begin{array}{l}(I P) \\
\text { Mean } \pm \\
\text { S.D. }\end{array}$ & $\begin{array}{l}I \text { (ICNB) } \\
\text { Mean } \pm \\
\text { S.D }\end{array}$ & $\begin{array}{l}\text { Ill(iv BUT) } \\
\text { Mean } \pm \text { S.D }\end{array}$ & $\begin{array}{l}\mathrm{IV}(\mathrm{CONT}) \\
\text { Mean } \pm \\
\text { S.D }\end{array}$ & $P_{\text {value }}$ \\
\hline 0 & $\begin{array}{l}0.92 \pm \\
1.97\end{array}$ & $\begin{array}{l}0.64 \pm \\
1.65\end{array}$ & $0 \pm 0$ & $2.4 \pm 2.08$ & 0.003 \\
\hline 1 & $\begin{array}{l}0.44 \pm \\
0.76\end{array}$ & $0.6 \pm 0.86$ & $0.24 \pm 0.83$ & $2.24 \pm 2.29$ & 0.000001 \\
\hline 2 & $\begin{array}{l}0.92 \pm \\
0.90\end{array}$ & $\begin{array}{l}1.12 \pm \\
1.05\end{array}$ & $1.92 \pm 1.41$ & $1.92 \pm 1.9$ & 0.01 \\
\hline 4 & $\begin{array}{l}2.44 \pm \\
1.52\end{array}$ & $2 \pm 1.52$ & $2.84 \pm 1.95$ & $1.52 \pm 1.47$ & 0.03 \\
\hline 8 & $\begin{array}{l}1.96 \pm \\
2.31\end{array}$ & $2.6 \pm 2.16$ & $0.96 \pm 1.48$ & $2 \pm 1.89$ & 0.03 \\
\hline 12 & $\begin{array}{l}1.08 \pm \\
1.44\end{array}$ & $\begin{array}{l}1.24 \pm \\
1.80\end{array}$ & $2.4 \pm 1.77$ & $1.8 \pm 1.97$ & 0.03 \\
\hline 16 & $\begin{array}{l}2.04 \pm \\
1.45\end{array}$ & $0.92 \pm 1.28$ & $2.32 \pm 2.01$ & $2.36 \pm 1.68$ & 0.006 \\
\hline 24 & $\begin{array}{l}1.76 \pm \\
1.16\end{array}$ & $\begin{array}{l}0.96 \pm \\
1.17\end{array}$ & $1.56 \pm 1.04$ & $2.24 \pm 1.33$ & 0.002 \\
\hline
\end{tabular}

The difference in VAS in all the four groups was statistically highly significant at $1 \mathrm{hr}, 16 \mathrm{hrs}$ and $24 \mathrm{hrs}(\mathrm{p}<0.005)$; and was significant at $0 \mathrm{hr}, 3 \mathrm{hrs}$, 4hrs, 8 hrs and 12 hrs. $(\mathrm{p}<0.05)$.

Table 3: Mean post-operative duration of analgesia (in hours)

\begin{tabular}{|l|l|l|l|}
\hline Group & Mean & S. D. & P value \\
\hline I(IP) & 6.54 & 4.63 & \multirow{2}{*}{0.0000} \\
II(ICNB) & 9.48 & 4.44 & \\
III(iv BUT) & 5.04 & 1.73 & \\
IV(CONT) & 1.50 & 1.60 & \\
\hline
\end{tabular}

The duration of analgesia was maximum in group II and least in group IV which was highly significant $(\mathrm{p}<0.0005)$.

Table 4: Number of rescue (analgesic) doses required in 24 hours post-operatively

\begin{tabular}{|l|l|l|l|}
\hline Group & Mean & S. D. & P value \\
\hline I(IP) & 1.4 & 0.70 & \\
II(ICNB) & 0.88 & 0.52 & 0.00 \\
III(iv BUT) & 2.08 & 0.57 & \\
IV(CONT) & 1.88 & 0.52 & \\
\hline
\end{tabular}

Maximum number of rescue analgesic doses were required in group III and least in group II which is statistically highly significant $(\mathrm{p}<0.005)$.

Table 5: Number of patients having shoulder pain 24 hours post-operatively

\begin{tabular}{|l|l|l|l|l|l|}
\hline Score & I(IP) & II(ICNB) & $\begin{array}{l}\text { III(iv } \\
\text { BUT })\end{array}$ & IV(CONT) & P value \\
\hline 1 & 20 & 19 & 20 & 19 & 0.84 \\
2 & 2 & 2 & 3 & 3 & 0.80 \\
3 & 2 & 2 & 1 & 2 & 0.77 \\
4 & 1 & 2 & 1 & 1 & 0.93 \\
5 & - & - & - & - & - \\
\hline
\end{tabular}

Shoulder pain was comparable in all the four groups ( $\mathrm{p}>0.05)$.

Table 6: Inter group comparison of mean number of rescue (analgesic) doses required in 24 hours post operatively.

\begin{tabular}{|l|l|l|}
\hline Groups & Bonferroni't - test & Inference \\
\hline I(IP) vs II (ICNB) & 0.004 & Significant \\
I(IP) vs III (iv BUT) & 0.0004 & Highly significant \\
I(IP) vs IV (CONT) & 0.008 & Significant \\
II(ICNB) vs III(iv & 0.0000 & Highly Significant \\
BUT) & 0.0000 & Highly Significant \\
II(ICNB) vs IV & 0.19 & Insignificant \\
$\begin{array}{l}\text { (CONT) } \\
\text { III (iv BUT ) vs IV } \\
\text { (CONT) }\end{array}$ & \\
\hline
\end{tabular}

Table 7: Side-effects seen 24 hours postoperatively

\begin{tabular}{|l|l|l|l|l|}
\hline $\begin{array}{l}\text { Side- } \\
\text { effects }\end{array}$ & I(IP) & II(ICNB) & III(IV BUT) & IV(CONT) \\
\hline Nausea & $2(8 \%)$ & $2(8 \%)$ & $3(12 \%)$ & $2(8 \%)$ \\
Vomiting & $1(4 \%)$ & $1(4 \%)$ & $2(8 \%)$ & $2(8 \%)$ \\
Any other & - & - & - & - \\
\hline
\end{tabular}




\section{Discussion:}

The difference in VAS in group I (IP), group II (ICNB), group III (i.v. BUT), and group IV (CONT) was found to be statistically highly significant at 1,16 and $24 \mathrm{hrs}\left(\mathrm{P}_{\text {value }}<0.005\right)$ and significant at $0,2,4,8$ and $12 \mathrm{hrs}\left(\mathrm{P}_{\text {value }}<\right.$ 0.05 )(Table 2). In our study, the pain relief in group I was noted up to $6.54 \pm 4.63 \mathrm{hrs}$. i.e VAS $<6$ post-operatively $\left(\mathrm{P}_{\text {value }}=0.0000\right)($ Table 3$)$. These findings are consistent with the findings of Neerja Bhardhwaj et al, who used $20 \mathrm{ml}$ of $0.5 \%$ bupivacaine with 1: 200000 adrenaline ${ }^{6}$. They noted pain relief up to $8 \mathrm{hrs}$, and less shoulder pain and analgesic requirement post-operatively. Narchi et al also found that post-operative pain relief by intraperitoneal LA instillation lasted for $48 \mathrm{hrs}$ in patients undergoing diagnostic laparoscopy ${ }^{7}$. D. J. Alexander et al demonstrated that direct periportal injection of bupivacaine at the level of parietal peritoneum reduces pain ${ }^{8}$.

Our study is in contrast to the studies by Rademaker et al and Joris et al using $20 \mathrm{ml}$ of $0.25 \%$ bupivacaine or $0.5 \%$ lignocaine and $80 \mathrm{ml}$ of $0.125 \%$ bupivacaine with adrenaline respectively, who failed to demonstrate any reduction in post-operative pain $^{9,10}$. Scheinin et al also found no relief of pain after administration of $100 \mathrm{ml}$ of either $0.15 \%$ plain bupivacaine alone or with adrenaline ${ }^{11}$. While Chundrigar et al showed pain relief only up to two hours with intraperitoneal administration of $0.25 \%$ bupivacaine ${ }^{12}$. All these negative results could be related to the lower concentrations and lower volumes of local anaesthetic used by them as compared to our study which has given good results.

Group II patients experienced pain relief for up to $9.48 \pm 4.44 \mathrm{hrs}$ post-operatively $\left(\mathrm{P}_{\text {value }}=\right.$ 0.0000 )(table. 3) which is in conformation with the study by Moore et al and Nunn and Slavin who demonstrated the mean duration of right abdominal analgesia of $12.3 \mathrm{hrs}$ postoperatively $^{13,14}$.

Group III patients had pain relief up to 5.04 $\pm 1.73 \mathrm{hrs}$ post-operatively $\left(\mathrm{P}_{\text {Value }}=0.0000\right)$ (table 3).Analgesia obtained was good but of shorter duration, which is consistent with the study conducted by Galloway et al ${ }^{15}$. Patients belonging to group IV noted mean duration of pain free period of $1.5 \pm 1.60 \mathrm{hrs}$ which is highly significant $\left(\mathrm{p}_{\text {value }}=0.0000\right)($ table 3$)$.
In our study patients received rescue analgesia when VAS $\geq 6$, which consisted of diclofenac sodium $75 \mathrm{mg}$ i.m. The mean number of rescue analgesic doses required in group I were $1.4 \pm$ $0.7\left(\mathrm{P}_{\text {value }}=0.00\right)($ table 4$)$, which is in concordance with the study of Neerja Bhardwaj et $\mathrm{al}^{6}$. In group II were $0.88 \pm 0.52\left(\mathrm{P}_{\text {value }}=\right.$ $0.00)$ (table. 4), thus going in favour of studies by Moore et $\mathrm{al}^{13}$, Nunn and Slavin ${ }^{14}$. In group III the mean number of rescue analgesic doses required were $2.08 \pm 0.57\left(\mathrm{P}_{\text {value }}=0.00\right) \quad($ Table 4$)$, supporting the studies done by Galloway et $\mathrm{al}^{15}$ and Tavakoli et al ${ }^{16}$. Group IV patients received rescue analgesia when VAS $\geq 6$ and the mean number of rescue analgesic dose required were $1.88 \pm 0.52$ ( $\mathrm{p}$ value $=0.00$ ). Thus rescue analgesic requirement was more in groups III and IV as compared to group I and was least in group II(table4 and 6).Intensity and severity of shoulder pain was statistically insignificant $\left(\mathrm{P}_{\text {value }}>0.05\right)$ in all the four groups (Table 4$)$.

Haemodynamic variables were found to be statistically insignificant in all the groups ${ }^{6,13}$.

Side-effects like nausea and vomiting were slightly more in patients in group III which were statistically insignificant (Table 7).Disadvantage of nausea and vomiting associated with opioids are avoided by intercostal nerve block ${ }^{17}$. No severe systemic toxic reactions or pneumothorax have resulted from intercostal block in our series $^{17}$.

From the results we derived that i.v. butorphanol produced excellent analgesia of shorter duration $(5.04 \pm 1.73 \mathrm{hrs})$, with slightly more incidence of nausea and vomiting which was statistically insignificant; intraperitoneal instillation and port-site infiltration with bupivacaine provided comparable analgesia but of somewhat longer duration $(6.54 \pm 4.63 \mathrm{hrs})$ with no major side effect; intercostal nerve block produced safe and effective analgesia of longer duration (9.48 \pm 4.44hrs) amongst the four groups with almost negligible side effects.

\section{References}

1. Mersky H. Pain terms: A list with definitions and notes on usage. Recommended by the IASP subcommittee on taxonomy. Pain 1979; 6: 24952 . 
2. Rees Brian I, Williams H R. Laparoscopic cholecystectomy the first 155 Patients. Ann R CollSurgEng 1992; 74 : 233-36.

3. Joris J, Cigarini I, Legrand M. Metabolic and respiratory changes after cholecystectomy performed via laparotomy. Br J Anaesth 1992; 69:341-45.

http://dx.doi.org/10.1093/bja/69.4.341 PMid:1419439

4. Edwards ND, Barclay K, Catling SJ. Day case laparoscopy: A survey of post-operative and assessment of the value of diclofenac.

Anaesthesia 1991; 46:1077-80.

http://dx.doi.org/10.1111/j.1365-

2044.1991.tb09930.x

PMid:1838235

5. Partridge BD, Stabile BE. The effects of incisional bupivacaine on post-operative narcotic requirements, oxygen saturation and length of stay in the post anaesthesia care unit.ActaAnaesthesiolScand 1990; 34:486-91. http://dx.doi.org/10.1111/j.1399-

6576.1990.tb03129.x

PMid:2239122

6. Bhardwaj Neerja, Sharma Vikas, Chari Pramila. Intraperitoneal bupivacaine instillation for post-operative pain relief after laparoscopic cholecystectomy. Indian J Anaesth 2002; 46 : 49-52.

7. Narchi P, Benhamou D, Fernandez H. Intraperitoneal local anaesthetic for shoulder pain after day case laparoscopy. The Lancet,1991; 338:1569-70. http://dx.doi.org/10.1016/0140-6736(91)92384$\underline{\mathrm{E}}$

8. Alexander DJ, Ngoi SS, So J, Mak K, Chan S and Goh PM. Randomized trial of periportal peritoneal bupivacaine for pain relief after laparoscopic cholecystectomy. Br J of Surg 1996; 83: 1223-25.

http://dx.doi.org/10.1002/bjs.1800830914 PMid:8983611

9. Rademaker BMP, Kalkman CJ, Odoom JA, de Wit L. Intraperitoneal local anaesthetics after laparoscopic cholecystectomy effects on postoperative pain, metabolic responses and lung function.Br J Anaesth 1994; 72 : 263-66. http://dx.doi.org/10.1093/bja/72.3.263 PMid:8130042

10 Joris J, Thiry E, Paris P, Weerts J, Lamy M. Pain after laparoscopic cholecystectomy: characteristics and effect of intraperitoneal bupivacaine. AnaesthAnalg 1995; 81: 379- 84.
11. Scheinin B, Kellokumpu I, Lindgren L, Hagulund C. Effect of intraperitoneal bupivacaine on pain after laparoscopic cholecystectomy. ActaAnaesthesiolScand 1995; 39: 195- 98. http://dx.doi.org/10.1111/j.13996576.1995.tb04042.x

PMid:7793186

12. ChundrigarTarig, Morris Russ, Hedges A Richard, Stamatakis Jeffrey D. Intraperitoneal bupivacaine for effective pain relief after laparoscopic cholecystectomy. Ann R CollSurgEng 1993; 75:437-39.

13. Moore DC, Bridenbaugh PO Thompson GE: Bupivacaine HCL: A summary of investigational use in 3274 cases. AnaesthAnalg 1971; 41: 1.

14. Nunn JF, Slavin G. Posterior intercostal nerve block for pain relief after cholecystectomy.Br J Anaesth 1980; 52:253-59. http://dx.doi.org/10.1093/bja/52.3.253 PMid:7370141

15. Galloway FM, Hrdlicka J, Losada M, Noveck RJ, Caruso FS. Comparison of analgesia by intravenous butorphanol and meperidine in patients with post-operative pain. Can AnaesthSoc J 1977; 24: 90-102. http://dx.doi.org/10.1007/BF03006816 PMid:318908

16. Tavakoli M, Corssen G, Caruso FS. Butorphanol and morphine: A double blind comparison of their parenteral analgesic activity. Anaesth and Analg 1976; 55: 394-401. http://dx.doi.org/10.1213/00000539-197605000$\underline{00025}$

PMid:776040

17 Moore DC. Intercostal nerve block for postoperative somatic pain following surgery of thorax and upper abdomen.Br J Anaesth 1975; 47: 284

PMid:1148103 